\title{
AMELIORATIVE EFFECTS OF MELATONIN AGAINST 2,4-DICHLOROPHENOXYACETIC ACID TOXICITY IN KIDNEY OF MICE - A HISTOLOGICAL STUDY
}

\author{
ASHLESH M UPADHYAYA, MANDAVA V RAO, DEVENDRASINH D JHALA* \\ Department of Zoology, Biomedical Technology and Human Genetics, University School of Sciences, Gujarat University, \\ Ahmedabad - 380 009, Gujarat, India. Email: ddjhala@gmail.com
}

Received: 08 August 2017, Revised and Accepted: 27 September 2017

\section{ABSTRACT}

Objective: The compound, 2,4-dichlorophenoxyacetic acid (2,4-D), is a systemic phenoxy herbicide and a plant growth regulator. Histopathological effects of 2,4-D alone and in combination with melatonin on the kidney in adult albino male mice of the Swiss strain were evaluated in the present study.

Methods: Twenty adult male albino mice weighing between 30 and 40 g were assigned into four groups with five mice in each group. Group I served as control; Group II - melatonin alone (10 mg/kg body weight); Group III - 2,4-D alone (50 mg/kg body weight); and Group IV - 2,4-D + melatonin was given orally for 45 days.

Results: It revealed a significant reduction in the body and kidney weights $(\mathrm{p}<0.001$ and $\mathrm{p}<0.01$ respectively) of mice treated with 2,4 -D, while the body and kidney weights after treatment of melatonin and 2,4-D + melatonin were comparable to control. Histological study revealed that 2,4-D induced nephrotoxicity evidenced by various histological changes including shrinkage of the glomerulus, tubular dilation, hypertrophy of tubular epithelium, and degeneration of renal tubules.

Conclusion: Treating animals with the melatonin along with 2,4-D showed mitigative effects of melatonin and minimized the structural alteration in the kidney of mice appeared due to 2,4-D toxicity.

Keywords: 2,4-dichlorophenoxyacetic acid, Histopathology, Melatonin, Mice, Mitigation, Nephrotoxicity.

(C) 2018 The Authors. Published by Innovare Academic Sciences Pvt Ltd. This is an open access article under the CC BY license (http://creativecommons. org/licenses/by/4. 0/) DOI: http://dx.doi.org/10.22159/ajpcr.2018.v11i1.21829

\section{INTRODUCTION}

Pesticides have played a vital role in controlling agricultural, industrial, home, and public health pest worldwide [1,2]. However, their use poses animal and human health concerns because of their toxicity, widespread use, and release into the environment [3,4]. According to the World Health Organization, 3 million cases of pesticide poisoning occur every year, resulting in more than 250,000 deaths [5]. 2,4-dichlorophenoxyacetic acid (2,4-D) is a systemic phenoxy herbicide developed in the 1940s and still in use today [1]. There are over 1500 pesticide/herbicide products containing 2,4-D as the main ingredient [6].

Human and other living organisms are exposed to 2,4-D in many ways: By breathing contaminated air, drinking and bathing in contaminated water, contacting contaminated soil, eating contaminated food, ingesting contaminated dust, and while working with 2,4-D. While each kind of exposure may involve small amounts of 2,4-D, their cumulative effect poses a serious concern. In toxicity tests, significant adverse effects were noted in the blood [7] and kidneys [8-10]. 2,4-D toxicity in peripheral blood mononuclear cells is associated with significant oxidative properties of this compound, which is responsible for cell death mostly through the induction of apoptosis [7]. 2,4-D treatment showed a fair degree of derangement of renal functions with concomitant changes in the histological structure of the kidney [8-10]. Moreover, the increment in plasma urea and creatinine levels and the reduction of uric acid in plasma along with histopathological alterations of 2,4-D-treated rats reported by Tayeb et al. [8] also supported the impairment of renal functions. Teratogenic [11-13], genotoxic [14], neurotoxic [2,15-17], immunosuppressive [18], cytotoxic [19-20], and hepatotoxic [21-23] effects of 2,4-D have also been well documented.
Melatonin (N-acetyl-5-methoxytryptamine) is a secretory product of the pineal gland and a tryptophan-derived molecule with pleiotropic activities. The discovery of melatonin as an antioxidant was made in 1993 [24]. Numerous reports documented its antioxidant, anticancer, and free radical scavenging properties [25-27]. Melatonin as an antioxidant in cancer therapy, liver disease, pulmonary disease, and cardiovascular disease has been well described [28]. As a potent free radical scavenger, melatonin and its secondary and tertiary metabolites are able to neutralize numerous toxic oxygen derivatives. These metabolites are potent antioxidants against both reactive oxygen species and reactive nitrogen species [29].

The present study was conducted to evaluate protective effects of melatonin on the kidney histology against 2,4-D-induced toxicity.

\section{METHODS}

Chemicals

The herbicide, 2,4-D (CAS No. 94-75-7; Purity: $\geq 99.0 \%$ ), was obtained from Loba Chemie, Mumbai, India. Melatonin (CAS No. 73-31-4; Purity: $\geq 99.0 \%$ ) was obtained from HiMedia Laboratories, Mumbai, India. All chemicals utilized in hematoxylin and eosin staining were procured from Sigma-Aldrich (St. Louis, MO, USA), Merck (Darmstadt, Germany), and HiMedia Laboratories (Mumbai, India) (AR grade).

\section{Experimental animals}

Healthy, adult male albino mice of the Swiss strain weighing between 30 and 40 g obtained from Zydus Cadila Pharmaceutical, Ahmedabad, Gujarat, India, were used for all experiments. Animals were kept in the Animal House of Zoology Department of Gujarat University, Ahmedabad, India, under controlled conditions (temperature $22 \pm 3^{\circ} \mathrm{C}, 12 \mathrm{~h}$ light/ dark cycle, and relative humidity 50-55\%). They were fed with 
certified pelleted rodent feed supplied by Amrut Feeds, Pranav Agro Industries Ltd., Pune, India, and water ad-libitum. All the experimental protocols were approved by the Committee for the Purpose of Control and Supervision of Experiments on Animals (Reg-167/1999/CPCSEA), New Delhi, India. Animals were handled according to the guidelines published by the Indian National Science Academy, New Delhi, India (2000) [30].

\section{Treatment}

As shown in Table 1,20 mice weighing between 30 and $40 \mathrm{~g}$ were divided into four groups with five mice in each group for 45-day treatment. Group I served as control; Group II was given oral administration of melatonin alone (10 mg/kg body weight), while Group III was given oral administration of 2,4-D (50 mg/ kg body weight) and in Group IV 2,4-D along with melatonin was given at the same dose level as those in Group III and II, respectively.

After completion of the 45 -day treatment, on the $46^{\text {th }}$ day, the body weight of each group of mice was recorded on an animal weighing balance (OHAUS, USA) to the nearest gram and sacrificed by cervical dislocation. The kidney was dissected out carefully, blotted free of blood, weighed to the nearest gram, and utilized to study the histopathology.

\section{Histopathology}

Histopathological studies were carried out using the standard technique of hematoxylin and eosin staining [31]. The fresh pieces of the kidney were fixed for $18 \mathrm{~h}$ in alcoholic Bouin's fixative. The tissue was dehydrated by passing through ascending grades of alcohol, cleared in xylene, and embedded in paraffin wax. About $5 \mu \mathrm{m}$ thick sections were cut on a rotary microtome and stained with Ehrlich's hematoxylin and eosin (alcohol soluble), dehydrated in alcohol, cleared in xylene, mounted in DPX, and examined microscopically.

\section{Statistical analysis}

All the data are expressed as the mean \pm standard error. Statistical analysis was performed using GraphPad Prism software version 5.03. The data were statistically analyzed using one-way analysis of variance followed by Tukey's test. The level of significance was accepted at $\mathrm{p}<0.05$.

\section{RESULTS}

\section{Body and kidney weight}

As shown in Table 2, a significant reduction in whole body weight $(\mathrm{p}<0.001)$ and kidney weight $(\mathrm{p}<0.01)$ in 2,4 -D-treated mice was observed. Moreover, percent relative weights were also reduced. Melatonin administration ameliorated the adverse effect on the body $(p<0.05)$ and kidney $(p<0.01)$ weights significantly, and results were comparable to control, whereas melatonin alone had shown no effect.

\section{Histopathology}

Figs. 1-8 show transverse section of control and experimental groups of mice kidney with hematoxylin and eosin stain.

Histology of the kidney of control mice exhibited normal histo architecture. Melatonin alone group showed normal histoarchitecture

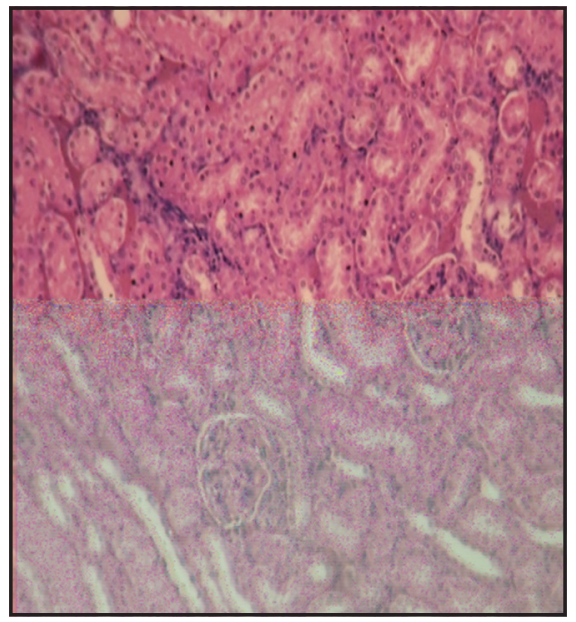

Fig. 1: Histology of control mice showed normal histoarchitecture (×210)

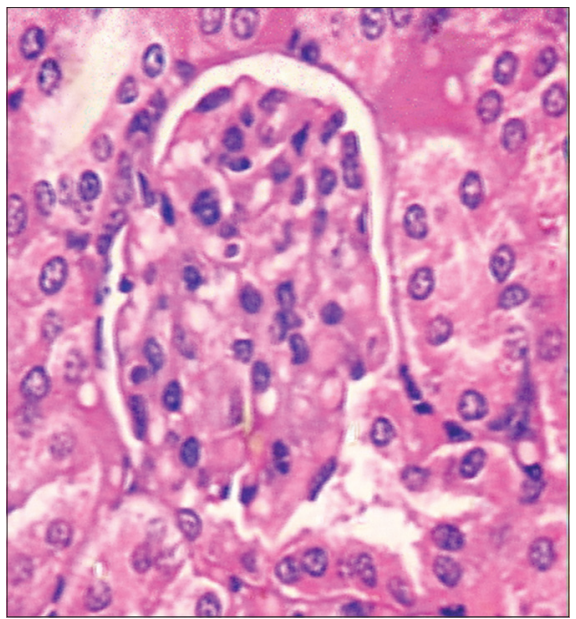

Fig. 2: Histology of control mice showed normal histoarchitecture $(\times 840)$

Table 1: Experimental groups

\begin{tabular}{llll}
\hline Groups & Treatment and dose & Duration & Day of autopsy \\
\hline I & Control (untreated) & 45 days & $46^{\text {th }}$ day \\
II & Melatonin alone (10 mg/kg body weight) & 45 days & $46^{\text {th }}$ day \\
III & $2,4-D(50 \mathrm{mg} / \mathrm{kg}$ body weight) & 45 days & $46^{\text {th }}$ day \\
IV & $2,4-\mathrm{D}+$ melatonin & 45 days & $46^{\text {th }}$ day \\
\hline
\end{tabular}

2,4-D: 2,4-dichlorophenoxyacetic acid

Table 2: Effect of melatonin on 2,4-D-induced changes in the body and kidney weights of mice

\begin{tabular}{lllll}
\hline Groups & Total body weight $(\mathbf{g})$ & Relative body weight $(\%)$ & Kidney weight $\mathbf{( g )}$ & Relative kidney weight (\%) \\
\hline I - Control & $38.60 \pm 1.43$ & 100 & $0.75 \pm 0.06$ & 100 \\
II - Melatonin & $40.00 \pm 1.55^{\mathrm{NS}}$ & 103.63 & $0.77 \pm 0.07^{\mathrm{NS}}$ & 102.67 \\
III - 2,4-D & $30.00 \pm 1.2^{* *}$ & 77.72 & $0.42 \pm 0.02^{*}$ & 56 \\
IV - 2,4-D + melatonin & $35.20 \pm 0.37^{\mathrm{NS} ; \#}$ & 91.19 & $0.72 \pm 0.06^{\mathrm{NS} ; \#}$ & 96 \\
\hline
\end{tabular}

Values are mean \pm SE, NS: Non-significant; ${ }^{*} \mathrm{p}<0.01 ;{ }^{* *} \mathrm{p}<0.001$ when Groups II to IV were compared with control (Group I); ${ }^{*} \mathrm{p}<0.05 ;{ }^{* *} \mathrm{p}<0.01$ when Group IV compared with Group III. 2,4-D: 2,4-dichlorophenoxyacetic acid, SE: Standard error 


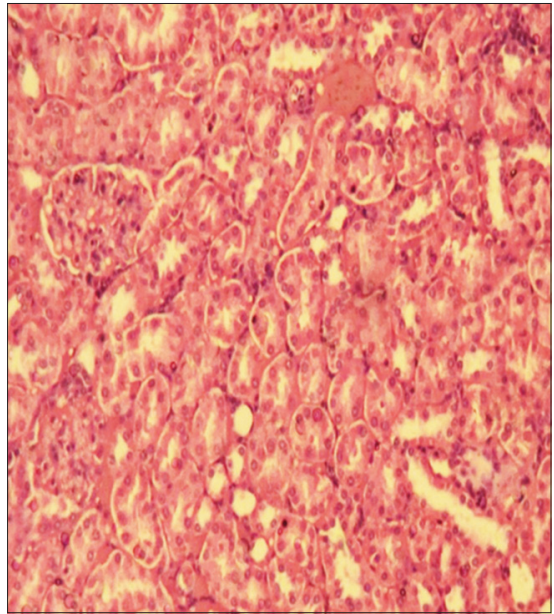

Fig. 3: Histology of melatonin treated mice showed normal histoarchitecture $(\times 210)$

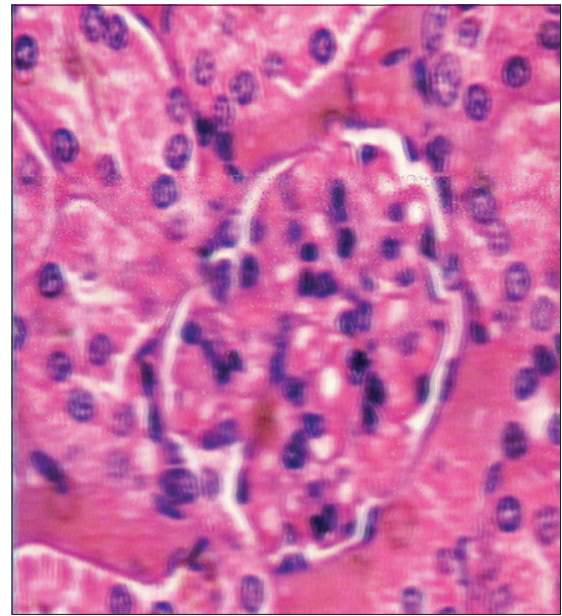

Fig. 4: Histology of melatonin treated mice showed normal histoarchitecture $(\times 840)$

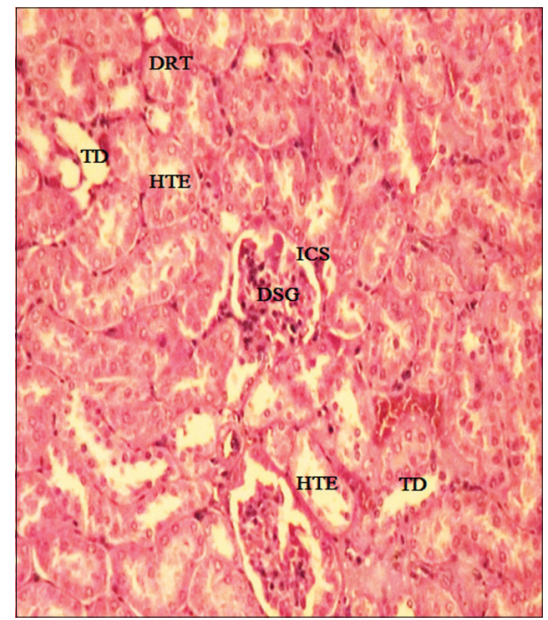

Fig. 5: Histology of 2,4-D treated mice exhibiting damaged and shrinkage of the glomerulus (DSG), increased capsular space (ICS), tubular dilation (TD), hypertrophy of tubular epithelium (HTE), degeneration of renal tubules (DRT), and vacuolization of proximal (VP) convoluted tubule $(\times 210)$

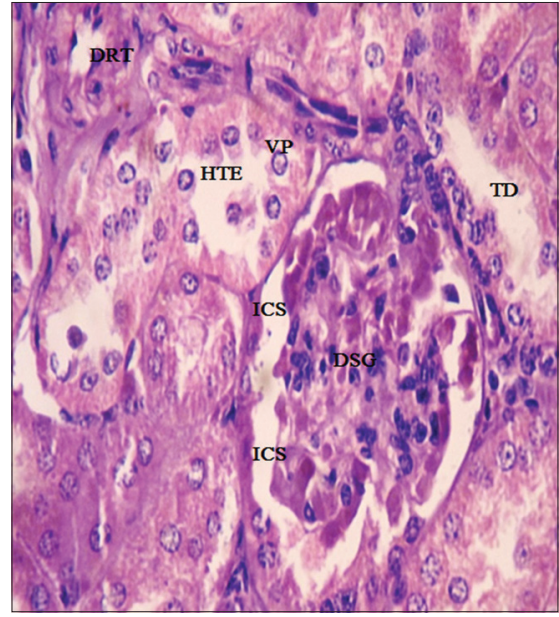

Fig. 6: Histology of 2,4-D treated mice exhibiting damaged and shrinkage of the glomerulus (DSG), increased capsular space (ICS), tubular dilation (TD), hypertrophy of tubular epithelium (HTE), degeneration of renal tubules (DRT), and vacuolization of proximal (VP) convoluted tubule $(\times 840)$

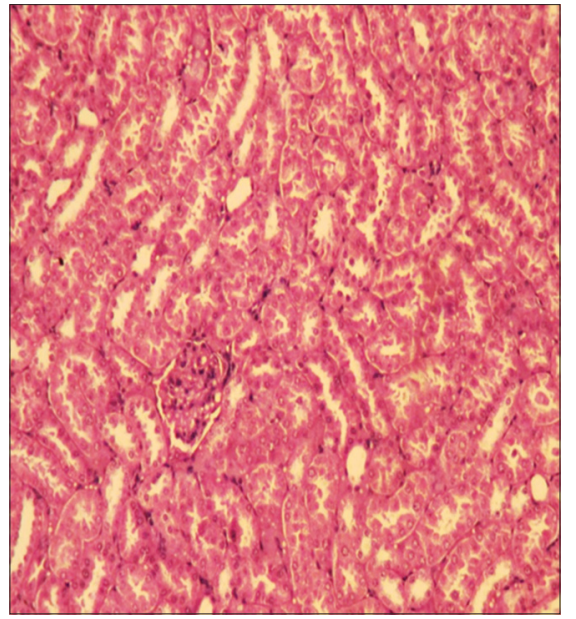

Fig. 7: Histology of 2,4-D + melatonin-treated mice showed the almost normal structure of the glomerulus and histoarchitecture were comparable to control $(\times 210)$

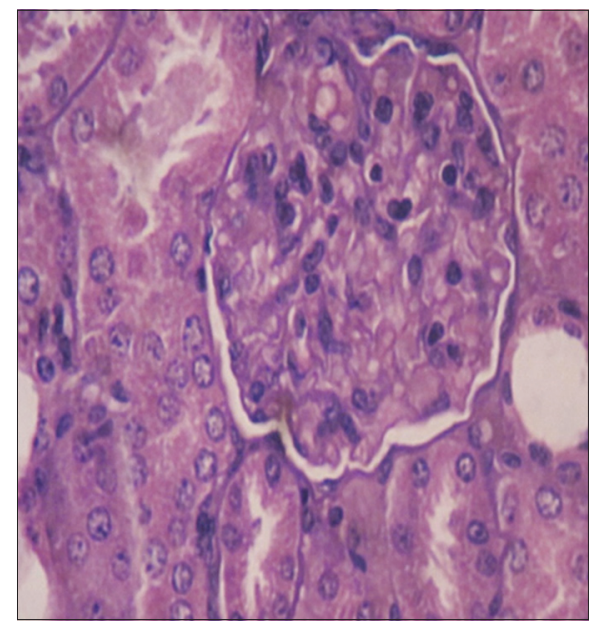

Fig. 8: Histology of 2,4-D + melatonin-treated mice showed the almost normal structure of the glomerulus and histoarchitecture were comparable to control $(\times 840)$ 
of the kidney as observed in the control group (Figs. 1-4). The 2,4-D-treated mice kidney revealed irregular organization of renal tubules with increased periglomerular space. Degenerative changes were also observed in the tubular epithelial cells. Animals had renal tubular necrosis and had degenerative changes in the glomerulus. The tubular endothelial cells exhibited abnormal morphology. The tubular lumen was also altered along with more extensive vacuolization of proximal convoluted tubule as compared to the distal convoluted tubule (Figs. 5 and 6). Amelioration of adverse histological effects was observed in kidney histoarchitecture of the mice supplemented 2,4-D with melatonin (Group IV) and were comparable to control (Figs. 7 and 8).

\section{DISCUSSION}

The results revealed that dose of 2,4-D (50 mg/kg body weight) for 45 days produced a significant reduction in the body and kidney weights. Our findings are in accordance with other earlier reports which have attributed the reduction in body and kidney weights due to reluctant food intake [8-10]. It is possible that 2,4-D may have suppressed the hunger centers of a central nervous system, resulting in decreased food intake. The mechanism by which the growth rate is inhibited by 2,4-D could be due to alteration in food intake as well as a reduction in protein synthesis.

It was observed that 2,4-D accumulated in the kidney [8-10] and might affect their structure. Hence, kidney exhibited degenerative changes gradually with cellular atrophy. Glomerular necrosis was also evident. In our study, further extensive vacuolization, disorganization of the renal tissue with increased periglomerular space, highly damaged, and distorted glomerulus along with degenerative changes in the tubular epithelial cells as well as in the glomerulus were observed. Our findings with regard to histopathology of 2,4-D-treated mice show an agreement with the results of Tayeb et al. [8] who reported histopathological damage and change in terms of severe glomerular atrophy, glomerular space, and tubular damages in 2,4-D-treated rat kidney. Another histopathological study of 2,4-D-treated rat kidney done by Uyanikgil et al. [10] revealed that renal corpuscular degeneration, vacuolization of proximal tubules, and epithelial change in distal tubules also support the observation of the present study.

The phenoxyacetic acid herbicides have previously been shown to accumulate at high levels in the liver and kidney through the organic acid transport system, and this accumulation depresses oxygen consumption by renal cortical slices and results in uncoupling of renal mitochondria raising the possibility of organ-specific toxicity secondary to transport [32]

According to the literature, 2,4-D is a weak peroxisome proliferator, and the rat is the species most sensitive to the nephrotoxic effects of peroxisome proliferators probably due to free radical-induced toxicity as reported in the liver to support these data $[21,33]$. There is a site specificity to this toxicity related to areas of peroxisome proliferation or related enzyme induction (namely proximal tubule cells), and 2,4-D is the most effective peroxisome proliferator at inducing renal lesions [34]. It is well known that peroxisome proliferator-activated receptor- $\alpha$ is highly expressed in the proximal tubule cells of the kidney [35]. Thus, it is noted that histological damages, observed in our study and proliferation of peroxisome, have affected both the tubular structure and the glomerular part. These morphological and functional alterations have affected kidney function.

It is well known that melatonin functions as a free radical scavenger and easily enters into the cells, subcellular compartments, as well as crosses the blood-brain barrier [28]. The protective effects of melatonin against 2,4-D were described by Bongiovanni et al. [16] in which they showed an amelioration by melatonin against oxidative stress produced by 2,4-D in rat cerebellar granular cells. Melatonin was shown as beneficial in preserving the renal function of rats against iron overload-induced toxicity and in renal ischemia-reperfusion injury by reducing lipid peroxidation, increasing glutathione levels, and preventing the increase in nitrite levels [36,37]. In this study also, administration of melatonin at a dose of $10 \mathrm{mg} / \mathrm{kg}$ body weight to 2,4-D-administered mice revealed ameliorative histological effects in the kidney. The histopathological alterations such as damaged and shrinkage of the glomerulus, increased capsular space, tubular dilation, and hypertrophy of tubular epithelium induced by 2,4-D had been normalized after administration of melatonin. Hence, this study confirmed mitigative effects of melatonin against 2,4-D-induced nephrotoxicity.

\section{CONCLUSION}

Oral administration of 2,4-D caused a reduction in body weight and kidney weight as well as alteration in the histopathology of the kidney, which could be responsible for its nephrotoxicity. Melatonin reduced 2,4-D-induced nephrotic changes. Protective effects of melatonin may be attributed due to its strong antioxidant properties.

\section{AUTHORS CONTRIBUTION}

Mr. Ashlesh M. Upadhyaya contributed in performing the experiment, data compilation and wrote the first draft of the manuscript. Dr. Mandava V. Rao and corresponding author, Dr. Devendrasinh D. Jhala were involved in experimental design, statistical analysis, corrections in the manuscript and overall management of the study. All authors read and approved the final manuscript.

\section{CONFLICT OF INTERESTS}

The authors confirm that this article content has no conflict of interest.

\section{REFERENCES}

1. Peterson MA, McMaster SA, Riechers DE, Skelton J, Stahlman PW. 2, 4-D past, present, and future: A review. Weed Technol 2016;30:303-45.

2. Bjørling-Poulsen M, Andersen HR, Grandjean P. Potential developmental neurotoxicity of pesticides used in Europe. Environ Health 2008;7:50.

3. Yang CC, Deng JF. Intermediate syndrome following organophosphate insecticide poisoning. J Chin Med Assoc 2007;70:467-72.

4. Sharma RK, Goyal AK. Agro-pesticides and andrology. Int J Pharm Pharm Sci 2014;6:12-9.

5. WHO. The Impact of Pesticides on Health: Preventing Intentional and Unintentional Deaths from Pesticide Poisoning. Geneva, Switzerland: World Health Organization; 2004.

6. Aylward LL, Hays SM. Biomonitoring equivalents (BE) dossier for 2,4-dichlorophenoxyacetic acid (2,4-D) (CAS No 94-75-7). Regul Toxicol Pharmacol 2008;51 3 Suppl:S37-48.

7. Bukowska B, Wieteska P, Kwiatkowska M, Sicinska P, Michalowicz J. Evaluation of the effect of 2,4-dichlorophenol on oxidative parameters and viability of human blood mononuclear cells (in vitro). Hum Exp Toxicol 2016;35:775-84.

8. Tayeb W, Nakbi A, Trabelsi M, Miled A, Hammami M. Biochemical and histological evaluation of kidney damage after sub-acute exposure to 2,4-dichlorophenoxyacetic herbicide in rats: Involvement of oxidative stress. Toxicol Mech Methods 2012;22:696-704

9. Tayeb W, Nakbi A, Miled A, Hammami M. The toxic effects of a commercial herbicide in various tissues of Wistar rats. J Res Environ Sci Toxicol 2013;2:71-9.

10. Uyanikgil Y, Ates U, Baka M, Biçer S, Oztas E, Ergen G. Immunohistochemical and histopathological evaluation of 2,4-dichlorophenoxyacetic acid-induced changes in rat kidney cortex. Bull Environ Contam Toxicol 2009;82:749-55.

11. Marouani N, Tebourbi O, Cherif D, Hallegue D, Yacoubi MT, Sakly M, et al. Effects of oral administration of 2,4-dichlorophenoxyacetic acid (2,4-D) on reproductive parameters in male Wistar rats. Environ Sci Pollut Res Int 2017;24:519-26.

12. Li K, Wu JQ, Jiang LL, Shen LZ, Li JY, He ZH, et al. Developmental toxicity of 2,4-dichlorophenoxyacetic acid in zebrafish embryos. Chemosphere 2017;171:40-8.

13. Tan Z, Zhou J, Chen H, Zou Q, Weng S, Luo T, et al. Toxic effects of 2,4-dichlorophenoxyacetic acid on human sperm function in vitro. J Toxicol Sci 2016;41:543-9.

14. Venkov P, Topashka-Ancheva M, Georgieva M, Alexieva V, KaranovE. Genotoxic effect of substituted phenoxyacetic acids. Arch Toxicol 2000;74:560-6. 
15. Amel N, Wafa T, Samia D, Yousra B, Issam C, Cheraif I, et al. Extra virgin olive oil modulates brain docosahexaenoic acid level and oxidative damage caused by 2,4-Dichlorophenoxyacetic acid in rats. J Food Sci Technol 2016;53:1454-64.

16. Bongiovanni B, De Lorenzi P, Ferri A, Konjuh C, Rassetto M, Evangelista de Duffard AM, et al. Melatonin decreases the oxidative stress produced by 2,4-dichlorophenoxyacetic acid in rat cerebellar granule cells. Neurotox Res 2007;11:93-9.

17. Bortolozzi AA, Evangelista De Duffard AM, Duffard RO, Antonelli MC. Effects of 2,4-dichlorophenoxyacetic acid exposure on dopamine D2like receptors in rat brain. Neurotoxicol Teratol 2004;26:599-605.

18. Pistl J, Kovalkovicová N, Holovská V, Legáth J, Mikula I. Determination of the immunotoxic potential of pesticides on functional activity of sheep leukocytes in vitro. Toxicology 2003;188:73-81.

19. Tuschl H, Schwab C. Cytotoxic effects of the herbicide 2,4-dichlorophenoxyacetic acid in HepG2 cells. Food Chem Toxicol 2003;41:385-93.

20. Rosso SB, Cáceres AO, de Duffard AM, Duffard RO, Quiroga S 2,4-Dichlorophenoxyacetic acid disrupts the cytoskeleton and disorganizes the Golgi apparatus of cultured neurons. Toxicol Sci 2000;56:133-40.

21. Rao MV, Satapathy A. Ameliorative effect of melatonin on 2,4-dichlorophenoxy acetic acid (2,4-d) exerted hepatotoxicity in mice. Bioscan 2016;11:2281-6.

22. Al-Baroudi DA, El-Kholy T, Arafat R, Ali A. The potential protective role of chamomile extract on rat liver ultrastructural changes induced by 2, 4-dichlorophenoxyacetic acid. J Diagn 2016;3:11-20.

23. Toledo-Ibarra GA, Díaz Resendiz KJ, Ventura-Ramón GH, GonzálezJaime F, Vega-López A, Becerril-Villanueva E, et al. Oxidative damage in gills and liver in Nile tilapia (Oreochromis niloticus) exposed to diazinon. Comp Biochem Physiol A Mol Integr Physiol 2016;200:3-8.

24. Tan DX, Chen LD, Poeggeler B, Manchester LC, Reiter RJ. Melatonin: A potent, endogenous hydroxyl radical scavenger. Endocr J 1993;1:57-60.

25. Hardeland R, Pandi-Perumal SR. Melatonin, a potent agent in antioxidative defense: Actions as a natural food constituent, gastrointestinal factor, drug and prodrug. Nutr Metab (Lond) 2005;2:22.

26. Reiter RJ, Acuña-Castroviejo D, Tan DX, Burkhardt S. Free radical- mediated molecular damage. Mechanisms for the protective actions of melatonin in the central nervous system. Ann N Y Acad Sci 2001;939:200-15.

27. Tan DX, Manchester LC, Terron MP, Flores LJ, Reiter RJ. One molecule, many derivatives: A never-ending interaction of melatonin with reactive oxygen and nitrogen species? J Pineal Res 2007;42:28-42.

28. Eghbal MA, Eftekhari A, Ahmadian E, Azarmi Y, Parvizpur A. A review of biological and pharmacological actions of melatonin: Oxidant and prooxidant properties. J Pharm Rep 2016;1:1-9.

29. Tan DX, Manchester LC, Esteban-Zubero E, Zhou Z, Reiter RJ. Melatonin as a potent and inducible endogenous antioxidant: Synthesis and metabolism. Molecules 2015;20:18886-906.

30. INSA. Guidelines for Care and Use of Animals in Scientific Research. New Delhi, India: Indian National Science Academy; 2000

31. Cardiff RD, Miller CH, Munn RJ. Manual hematoxylin and eosin staining of mouse tissue sections. Cold Spring Harb Protoc 2014;2014:655-8.

32. Pritchard JB, Krall AR, Silverthorn SU. Effects of anionic xenobiotics on rat kidney. I-tissue and mitochondrial respiration. Biochem Pharmacol 1982;31:149-55.

33. Kawashima Y, Katoh H, Nakajima S, Kozuka H, Uchiyama M. Effects of 2,4-dichlorophenoxyacetic acid and 2,4,5-trichlorophenoxyacetic acid on peroxisomal enzymes in rat liver. Biochem Pharmacol 1984;33:241-5.

34. Ozaki K, Mahler JF, Haseman JK, Moomaw CR, Nicolette ML, Nyska A. Unique renal tubule changes induced in rats and mice by the peroxisome proliferators 2,4-dichlorophenoxyacetic acid (2,4-D) and WY-14643. Toxicol Pathol 2001;29:440-50.

35. Braissant O, Foufelle F, Scotto C, Dauça M, Wahli W. Differential expression of peroxisome proliferator-activated receptors (PPARs): Tissue distribution of PPAR-alpha, -beta, and -gamma in the adult rat. Endocrinology 1996;137:354-66.

36. Abd-Elkader M, Aly H. Protective effect of melatonin against iron overload-induced toxicity in rats. Int J Pharm Pharm Sci 2015;7:116-21.

37. Rodríguez-Reynoso S, Leal C, Portilla-de Buen E, Castillo JC, RamosSolano F. Melatonin ameliorates renal ischemia/reperfusion injury. J Surg Res 2004;116:242-7. 